\title{
STRATEGI KOMUNIKASI LINGKUNGAN DALAM MEMBANGUN KEPEDULIAN MASYARAKAT TERHADAP LINGKUNGAN
}

\author{
Uud Wahyudin \\ Program Studi M anaj emen K omunikasi, Fakultas IImu K omunikasi, \\ Universitas Padjadjaran \\ uudwahyudin@yahoo.co.id
}

\begin{abstract}
Environmental problems in Indonesia can not only be rescue and response to disaster. Collective awareness is required to simultaneously protect the environment. Thus, more serious efforts are required in building and increasing human awareness of the environment so as not to experience disturbance and degradation of environmental quality. This is where the environmental communication management aspect is to communicate awareness and awareness of society and industry to the environment. Environmental communication is required as an effort to communicate environmental sustainability through environmental communication strategies that can build awareness and awareness of society $/$ industry to the environment.
\end{abstract}

Keyword : Enviromental communication, enviroment, communication management

\begin{abstract}
Abstrak
Permasalahan lingkungan hidup di Indonesia tidak bisa hanya diselesaikan dengan upaya penyelamatan dan tanggap terhadap bencana saja. Diperlukan kesadaran kolektif untuk secara bersama-sama menjaga lingkungan hidup. Dengan demikian, diperlukan upaya yang lebih serius dalam membangun dan meningkatkan kepedulian manusia terhadap lingkungan hidup agar tidak terus terjadi kerusakan dan penurunan kualitas lingkungan. Disinilah pentingnya manajemen komunikasi lingkungan guna mengomunikasikan kesadaran dan kepedulian masyarakat dan industri terhadap lingkungan hidup. Diperlukan komunikasi lingkungan sebagai upaya mengomunikasikan kelestarian lingkungan hidup melalui strategi komunikasi lingkungan hidup yang dapat membangun kesadaran dan kepedulian masyarakat/ industri terhadap lingkungan hidup.
\end{abstract}

Kata kunci: Komunikasi lingkungan, lingkungan hidup, manajemen komunikasi 


\section{Pendahuluan}

Bencana alam seperti banjir, longsor hingga kebakaran hutan di Indonesia semakin hari kian mengkhawatirkan. Tak terkecuali di Jawa Barat. Kejadian lonsor di Sumedang, banjir di Garut, banjir dan pohon tumbang di Kota Bandung dan Kabupaten Bandung beberapa waktu lalu merupakan alasan konkret perlunya kesadaran dan gerakan dalam mengelola dan melestarikan lingkungan hidup.

Selain itu, kerusakan lingkungan di Jawa Barat juga banyak disebabkan oleh pembuangan limbah industri. Dalam menjalankan aktivitas produksinya tidak menutup kemungkinan perusahaan/ industri akan memberikan dampak sampingan yang mengandung potensi masalah terhadap lingkungan, yang akan merusak lingkungan dan merugikan masyarakat sekitarnya. Kerusakan lingkungan yang disebabkan oleh perusahaan/industri saat ini sudah menjadi menjadi perhatian berbagai pihak baik di dalam negeri (nasional) maupun dunia (internasional).

Sebagai contoh, di tingkat nasional bencana ekologis nasional lumpur panas yang terjadi di Kabupaten Sidoarjo Provinsi Jawa Timur dimulai pada tanggal 28 Mei 2006, saat gas beracun dan lumpur panas menyembur di dekat sumur pengeboran Banjar Panji-1 milik kegiatan pengeboran PT Lapindo Brantas, Inc. yang hingga kini masih belum dapat dihentikan. Kegiatan eksplorasi minyak dan gas sebagaimana dilakukan oleh PT Lapindo Brantas, Inc. merupakan kegiatan survey seismic dan eksplorasi. Kegiatan tersebut merupakan rangkaian kegiatan yang dilakukan karena sifat cadangan minyak dan gas bumi yang berada di perut bumi tidak dapat ditentukan lokasinya secara pasti. Karena besarnya volume semburan menyebabkan air Lumpur tersebut dialirkan ke badan air Sungai Porong dan Sungai Aloo demi menjamin keselamatan jiwa masyarakat dan infrastruktur di sekitar lokasi semburan dan ini juga berdampak pada kerusakan ekosistem di sungai tersebut. Akibatnya semua pihak sangat dirugikan terutama masyarakat yang terkena dampak dari lumpur serta polusi udara yang di hasilkan dari lumpur Lapindo.

Polusi atau pencemaran lingkungan adalah masuknya atau dimasukkannya makluk hidup, zat energi, dan atau komponen lain ke dalam lngkungan atau berubahnya tatanan lingkungan oleh kegiatan manusia atau oleh proses alam sehingga kualitas lingkungan turun sampai ke tingkat tertentu yang menyebabkan lingkungan menjadi kurang atau tidak dapat berfingsi lagi sesuai dengan peruntukannya (UU Pokok Pengelolaan Lingkungan Hidup No. 4 Tahun 1982).

Pencemaran dapat timbul sebagai akibat kegiatan manusia ataupun disebabkan oleh alam (misal gunung meletus, gas beracun). Ilmu lingkungan biasanya membahas pencemaran yang disebabkan oleh aktivitas manusia, yang dapat dicegah dan dikendalikan.

Karena kegiatan manusia, pencermaran lingkungan pasti terjadi. Pencemaran lingkungan tersebut tidak dapat dihindari. Yang dapat dilakukan adalah mengurangi pencemaran, mengendalikan pencemaran, dan meningkatkan kesadaran dan kepedulian masyarakat terhadap lingkungannya agar tidak mencemari lingkungan.

Zat atau bahan yang dapat mengakibatkan pencemaran di sebut polutan. Syarat-syarat suatu zat disebut polutan bila keberadaannya dapat menyebabkan kerugian terhadap makluk hidup. Contohnya, karbon dioksida dengan kadar $0,033 \%$ di udara berfaedah bagi tumbuhan, tetapi bila lebih tinggi dari 0,033\% dapat memberikan efek merusak.(Mubarak, 2012 : 30-31)

Permasalahan lingkungan hidup di Indonesia tentu tidak bisa diselesaikan dengan upaya penyelamatan dan tanggap terhadap bencana saja. Diperlukan kesadaran kolektif untuk secara bersama-sama menjaga lingkungan hidup. Dengan demikian, 
diperlukan upaya yang lebih serius dalam membangun dan meningkatkan kepedulian manusia terhadap lingkungan hidup agar tidak terus terjadi kerusakan dan penurunan kualitas lingkungan.

Padahal sudah sangat jelas, bahwa Undang-Undang Nomor 32 Tahun 2009 tentang Perlindungan dan Pengelolaan Lingkungan (PPLH) lingkungan hidup adalah kesatuan ruang dengan semua benda, daya, keadaan dan makhluk hidup, termasuk manusia dan perilakunya, yang memengaruhi alam itu sendiri, kelangsungan perikehidupan dan kesejahteraan manusia serta makhluk hidup lain. Dari sisi hukum, pencemaran lingkungan ini dijerat Pasal 104 UndangUndang Nomor 32 Tahun 2009 tentang Perlindungan dan Pengelolaan Lingkungan Hidup dengan ancaman hukuman maksimal 3 tahun penjara atau denda maksimal $\mathrm{Rp} 3$ miliar.

Namun inilah fakta yang ada dan menjadi latar belakang pentingnya manajemen komunikasi lingkungan guna mengomunikasikan kesadaran dan kepedulian masyarakat dan industri terhadap lingkungan hidup.

\section{Pembahasan}

Komunikasi lingkungan sendiri adalah rencana dan strategi melalui proses komunikasi dan produk media untuk mendukung efektivitas pembuatan kebijakan, partisipasi publik, dan implementasinya pada lingkungan (Oepen, 1999:6). Dalam pengertian Oepen dapat dipahami bahwa komunikasi lingkungan menjadi komponen yang terintegrasi dalam kebijakan.

Selanjutnya, Robert Cox dalam bukunya Environmental Communication and the Public Sphere, mengemukakan bahwa komunikasi lingkungan adalah sarana pragmatis dan konstitutif untuk memberikan pemahaman mengenai lingkungan kepada masyarakat, seperti halnya hubungan kita dengan alam semesta. Ini merupakan sebuah media simbolik yang digunakan untuk menciptakan masalah lingkungan dan negosiasi perbedaan respon terhadap permasalah lingkungan yang terjadi. Dengan kata lain komunikasi lingkungan digunakan untuk menciptakan kesepahaman mengenai permasalahan lingkungan (Cox, 2010:20).

\section{Langkah dalam Strategi Komunikasi Lingkungan}

\section{Stage 1 Penilaian}

1. Analisis situasi dan identifikasi masalah

2. Analisis pihak/pelaku yang terlibat

3. Komunikasi objektif (untuk meningkatkan pengetahuan, mempengaruhi perilaku)

\section{Stage $2 \quad$ Perencanaan}

4. Pengembangan strategi komunikasi

5. Memotivasi dan memobilisir masyarakat

6. Pemilihan media

\section{Stage $3 \quad$ Produksi}

7. Desain pesan yang akan disampaikan

8. Produksi media disertai pretest

\section{Stage $4 \quad$ Aksi dan Refleksi}

9. Penyebaran melalui media dan implementasinya

10. Proses dokumentasi, monitoring, dan evaluasi

Strategi komunikasi harus dilakukan oleh komunikator yang tepat. Lebih lanjut, penelitian, proses monitoring yang berkelanjutan, dan evaluasi menjadi bagian penting dari perencanaan. Penggunaan media juga ditentukan oleh tujuan serta segmentasi audience pada setiap jenis media.

Lebih lanjut, dalam bukunya Environmental Communication and the Public Sphere, Robert Cox (2010) 
menjelaskan dua fungsi komunikasi lingkungan: (1) Komunikasi lingkungan adalah pragmatis. Ini bersifat edukasi dan membantu kita dalam menyelesaikan permasalahan komunikasi lingkungan. Awalnya ini berupa instrumen komunikasi yang terjadi pada kita, komunikasi dalam tindakan. Penyelesaian masalah dan perdebatan seringkali menjadi bagian dari kampanye edukasi publik. (2) Komunikasi lingkungan adalah konstitutif. Komunikasi lingkungan juga membantu dalam representasi alam dan permasalahan lingkungan yang juga merupakan subyek pemahaman bagi kita. Dengan membentuk persepsi kita tentang alam, komunikasi lingkungan mengajak kita untuk melihat hutan dan sungai sebagai ancaman atau kekayaan yang berlimpah dan juga sebagai sistem pendukung kehidupan yang vital dan sesuatu yang harus dihargai.

Komunikasi lingkungan bukanlah hal yang mudah untuk dilakukan. Agar komunikasi lingkungan dapat berjalan dengan lancar diperlukan sebuah strategi komunikasi yang disusun oleh komunikator (pemerintah daerah), sehingga komunikasi yang dilakukan dapat diterima dengan baik oleh komunikan (masyarakat/industri).

Strategi komunikasi merupakan langkah awal dan menjadi penentu dalam bagaimana komunikasi lingkungan akan dijalankan. Oleh karena itu, perlu dipertimbangkan banyak hal dengan memperhitungkan faktor-faktor pendukung atau faktor yang menghalanginya dengan memperhitungkan dan memperhatikan tahapan dan langkah-langkah dalam strategi komunikasi lingkungan.

Pertama, tahap penilaian, yang terdiri dari langkah analisis situasi dan identifikasi masalah, analisis pihak/pelaku yang terlibat, dan tujuan komunikasi. Masyarakat dan industri sebagai sasaran komunikasi lingkungan perlu dikenali agar pesan dapat disampaikan sesuai dengan situasi dan kondisi masyarakat dan industri yang akan dituju. Bila ternyata pencemaran lingkungan disebabkan oleh perilaku masyarakat dan industri yang masih enggan berperilaku dan belum adanya kesadaran terhadap kelestarian lingkungan hidup, sudah saatnya masyarakat dan industri sebagai stakeholder utama dari setiap program komunikasi lingkungan akan lebih manis bila ditempatkan sebagai pelaku utama dalam melestarikan lingkungan hidup. Selanjutnya, tujuan awal komunikasi lingkungan perlu dikaji dengan baik agar pesan dapat dibentuk dan disesuaikan dengan tujuan komunikasi.

Kedua, tahap perencanaan yang terdiri dari pengembangan strategi komunikasi, memotivasi dan memobilisasi masyarakat dan industri, dan pemilihan media. Strategi komunikasi harus dilakukan oleh komunikator yang tepat. Berikutnya, penggunaan beberapa jenis media dalam suatu komunikasi dapat saja terjadi, namun kelebihan dan kekurangan dari tiap media perlu diperhitungkan agar sesuai dengan situasi dan kondisi komunikasi. Gunakan komunikasi interpersonal, edukasi, dan konseling. Selain itu, media massa, baik media cetak maupun media elektronik dapat digunakan untuk menumbuhkan kesadaran dan kepedulian masyarakat dan industri terhadap kelestarian lingkungan hidup. Selanjutnya, praktikkan social marketing dan mobilisasi dengan konsep kampanye komunikasi lingkungan hidup.

Menurut M Jamiludin Nur dalam artikelnya di Surat Kabar Pikiran Rakyat (29/4/2017), bahwa media massa memiliki kekuatan dalam menyebarkan informasi. Daya jangkau media massa juga mampu hadir di berbagai lapisan sosial, ekonomi, dan politik. Dengan perannya sebagai salah satu sumber informasi untuk memperoleh pengetahuan dan wawasan, media massa sejatinya dapat digunakan sebagai salah satu instrumen untuk mengelola dan melestarikan lingkungan. Hal ini tentu dapat dilakukan 
melalui konten dan pemberitaan yang menarik. Senada dengan itu, Lippman (dalam Schramm, 1970) menegaskan media berperan dalam penyebaran informasi sekaligus dapat membentuk persepsi khalayak sehingga melalui media massa seperti surat kabar, radio, dan TV masyarakat dapat mengetahui apa yang terjadi di sekitar mereka dan di tempat lain. Oleh karena itu, media memberikan ruang informasi yang memadai untuk isu lingkungan hidup patut untuk kita apresiasi. Jika media massa rajin menampilkan dan menyebarkan informasi yang mampu membangun kepedulian terhadap lingkungan, diharapkan masyarakat akan memiliki wawasan dan kesadaran untuk menjaga dan melestarikan lingkungan hidup.

Ketiga, tahap produksi pesan yang terdiri dari langkah desain pesan dan produksi media. Pesan-pesan komunikasi lingkungan harus lebih diarahkan pada upaya mengubah kebiasaan yang tidak peduli terhadap lingkungan hidup. Misalnya melakukan sosialisasi tentang "JANGAN MEMBUANG SAMPAH DAN LIMBAH DI SUNGAI".

Keempat, tahap aksi dan refleksi yang terdiri dari langkah penyebaran melalui media dan langkah dokumentasi, monitoring, dan evaluasi. Upaya penyadaran dan kepedulian masyarakat dan industri terhadap lingkungan hidup melalui komunikasi lingkungan kuncinya ada pada prioritas dan komitmen politik pemerintah. Dalam komunikasi lingkungan, penyebaran pesan melalui beberapa jenis media, proses monitoring yang berkelanjutan, dan evaluasi menjadi bagian penting yang harus dilakukan pemerintah daerah.

\section{Kesimpulan}

Pada akhirnya, dengan pola penanganan pemerintah daerah yang masih seperti sekarang dan kesadaran masyarakat yang masih rendah, diperkirakan tidak akan ada kemajuan dalam membangun kesadaran masyarakat dan industri terhadap kelestarian lingkungan hidup. Diperlukan political will pemerintah daerah dalam mengomunikasikan kelestarian lingkungan hidup melalui strategi komunikasi lingkungan hidup yang dapat membangun kesadaran dan kepedulian masyarakat/ industri terhadap lingkungan hidup.

Terakhir, upaya membangun dan melestarikan lingkungan hidup harus dilakukan secara integratif antara pemerintah, NGO, media massa, perusahaan/industri dan masyarakat. Melestarikan dan menjaga lingkungan hidup bukan hanya tugas pemerintah (daerah) saja, melainkan tugas dan tanggung jawab segenap lapisan masyarakat.

\section{Daftar Pustaka}

Notoatmojo, Soekijo. Promosi Kesehatan dan IImu Perilaku Kesehatan. Jakarta: PT. Raja Grafindo Persada.

Mubarak, Ikbal Wahit. 2012. IImu Kesehatan M asyarakat. Jakarta. Salemba Medika

Oepen, Manfred and Hamacher, Winfried. 1999. Environmental Communication for Sustainable D evelopment.

Cox, Robert. 2010. Environmental Communication and the Public Sphere. Sage Publication. 